\title{
UTILIZATION OF SPACE TO REALIZE A GREEN ALLEY IN CIBOGOR VILLAGE, BOGOR CITY
}

\author{
Tatan SUKWIKA \\ Environmental Engineering, Sahid University Jakarta, Indonesia \\ tatan.swk@gmail.com
}

\begin{abstract}
Greening activities along the alley by the housewives and several youths in RT01/RW03, Cibogor Village, Bogor City. Plant management is still individual or not collective and not in a neat and unplanned way. Therefore, it is necessary to assist the management of plants in the alley as a beginner step towards creating an attractive green. The purpose of the Community Service program is the optimal management of space along the alley for reforestation to create beauty and cleanliness in the alley environment. In this activity, the material taught is to carry out socialization activities to residents; Carry out training/assistance on plant management activities; and Carry out plant arrangement activities in the alley room and evaluate the understanding of the residents before and after the mentoring. The application of community service through plant arrangement activities in the alley room using this mentoring method is useful for introducing and practising and is easily applied at the community level. Technical assistance provided to residents based on residents' preferences in creating greenery in front of beautiful alleys. Efforts to optimize space along the alley have succeeded in creating beauty and cleanliness in the alley environment. The managerial implication is the residents can adopt other alley space utilization techniques by presenting various plants available around residents' homes such as varied from fruit plants, vegetables, medicinal, and ornamental plants.
\end{abstract}

Keywords: Capaciy Building, Alley Greening, Management of Plants

\section{BACKGROUND}

Partners of this community service program are residents of Cibogor Village, Central Bogor DistrSIO, Bogor City. The determination of this partner is because this location has an open space along the alley where there are plant pots placed by residents sporadically and less organized (Al-Ghifari \& Firdausan, 2020; Joga \& Ismaun, 2011). This condition makes the alley environment looks less beautiful and unattractive. Most of the residents have worked as private employees, traders, and a few as civil servants. Where they leave every day in the morning and return in the afternoon or evening. Most residents are at home on Saturdays and Sundays. So far, plant management is not routine and unplanned, that is because the handling is still individual or not collective. The greening activities activity initiated by housewives and some local youths along the alley. Each resident asked to place plant pots and place them in front of the house fence.

Creating a green alley requires low cost and can even be funded from the neighbourhood association's treasury and self-help from the local community. Practice in several places has shown that creating green alleys can be successful if done collectively, planned, programmed. Assistance in arranging plants in the alley is the first step towards creating a green alley that is beautiful, fresh, and even clean of garbage (Noviana \& Sukwika, 2020; Sukwika \& Firmansyah, 2021). For this reason, it is necessary to provide knowledge on how to arrange these plants, so that residents understand how to manage green alleys easily by utilizing various small plants available around the residents' yards. The selection of plant species facilitates the maintenance and capture of optimal light as well as absorbs pollution to stimulate the photosynthesis process, increasing plant growth and productivity (Hasim, 2020; Irwan \& Sarwadi, 2016; Kusminingrum, 2008; Rosha et al., 2016).

The problems faced by partners are: (a)Arrangement of plant pots along the alley looks unorganized, messy and disturbing the view. (b) People's knowledge of utilizing space with the vertical method is still low. (c) The attitude of the residents regarding the use of space for reforestation along the alley is still individual or not collective. The target to be achieved in the community service activity plan is to use the space along the alley to make it look green and create a clean environment in the community. These targets can be detailed as follows: Partners who are residents of RT01/RW03 Kelurahan Cibogor, Bogor receive assistance in terms of (a) Optimizing the management of space along the alley for beauty and cleanliness in the alley environment. (b) Utilization of space to realize greenery along the side of the alley.

\section{METHOD \\ Approach Method}

Based on the agreement between the proposing team and partners, the solutions offered to overcome the problems, as follows: (1) The process of building human resource motivation through capacity building of citizens. The target of this process is that empowered resources have the desire to create a better environment through the use of open spaces as green alleys. (2) Utilization of space for plant arrangement with the vertical method using light steel shelves. (3) The mentoring process is carried out to maintain commitment, program continuity and create cohesive teamwork.

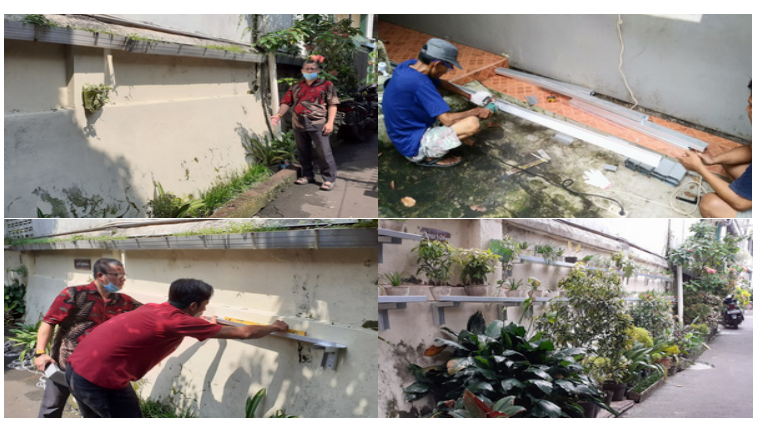

Figure 1. Photo of the Assistance Activity Process. 


\section{Stages of activity}

The stages in the application of community service are lectures, practices and discussions. It is described in more detail as follows: (1) Lecture. The lecture method is in the form of delivering material orally about make garden shelves, starting from giving participants an understanding of the parts of light steel shelves, including the function of mild steel, adhesive materials, and supporting tools. (2) Practice. At this stage, all participants demonstrated how to make shelves made of light steel provided and installed them on the alley walls. (3) Discussion. Community service activities ended with direct discussions with partner residents. Discussion activities are intended to equalize participants' understanding of the material that has been explained and practised.

\section{Procedures}

The working procedure of using open space to create green alleys is as follows: (1) implementation of outreach activities to community partners. (2) assistance in plant management activities. (3) implementation of plant arrangement activities in the alley space. (4) evaluation of community understanding before and after mentoring.

\section{RESULTS AND DISCUSSION}

Before the activity begins, there is a pre-test for the participants. This test determines the extent of the participants' initial understanding of the questions asked related to household lamps and the manufacturing process. At the end of the activity, there is a post-test. Here, participants will know the changes in their abilities according to the material that has been obtained. Evaluation of activity achievement against Specific Instructional Objectives (SIO) is based on measurement parameters, namely (1) General knowledge of participants about green alleys. (2) Participants' knowledge of vertical gardens. (3) Participants' knowledge of how to optimize space for the garden in the alley. (4) Participants' knowledge about the experience of how to arrange a garden in the alley. (5) Participants' knowledge about gardening with mild steel.

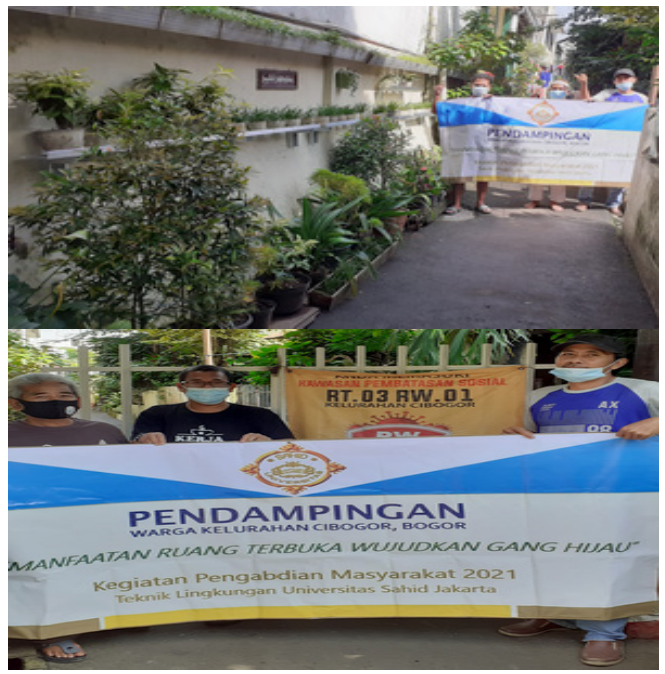

Figure 2. Photos of Assistance Activities Results.
The questions on the pre-test are the same as the questions on the post-test. The test is used to compare the results of training activities by compiling questions according to the Specific Instructional Objectives (SIO) to be achieved in this service activity. Information on the composition of SIO in the pre-test and post-test is presented in Table 1.

Table 1. the composition of SIO in the pre-test and post-test

\begin{tabular}{llccc}
\hline No & $\begin{array}{l}\text { Specific Instructional } \\
\text { Objectives (SIO) }\end{array}$ & $\begin{array}{c}\text { Question } \\
\text { points. }\end{array}$ & $\begin{array}{c}\text { Number } \\
\text { of } \\
\text { questions }\end{array}$ & Proportion \\
\hline $1 \quad$ & $\begin{array}{l}\text { Know a general } \\
\text { understanding of green } \\
\text { alleys. }\end{array}$ & 1,2 & 2 & 20 \\
$2 \quad \begin{array}{l}\text { Increase knowledge on } \\
\text { how to optimize space } \\
\text { for the garden in the } \\
\text { alley. }\end{array}$ & 3,4 & 2 & 20 \\
3 & $\begin{array}{l}\text { Increase knowledge } \\
\text { about the experience } \\
\text { of how to arrange a } \\
\text { garden in the alley. }\end{array}$ & 5,6 & 2 & 20 \\
4 & $\begin{array}{l}\text { Increase knowledge } \\
\text { about vertical gardens. }\end{array}$ & 7,8 & 2 & 20 \\
5 & $\begin{array}{l}\text { Increase knowledge } \\
\text { about gardening with } \\
\text { mild steel. }\end{array}$ & 9,10 & 2 & 20 \\
\hline
\end{tabular}

The results of Table 1 and Table 2 are compared to determine the change in the percentage increase in SIO achievement, namely before service activities and after service activities.

Table 2. Comparison of SIO achievements before and after service

\begin{tabular}{|c|c|c|c|c|}
\hline \multirow{2}{*}{ No. } & \multirow{2}{*}{$\mathrm{SIO}$} & \multicolumn{3}{|c|}{ Achievement SIO (\%) } \\
\hline & & Before & After & Increase \\
\hline 1 & $\begin{array}{l}\text { Know a general } \\
\text { understanding of green } \\
\text { alleys. }\end{array}$ & 35.21 & 83.76 & 48.55 \\
\hline 2 & $\begin{array}{l}\text { Increase knowledge about } \\
\text { vertical gardens. }\end{array}$ & 43.42 & 90.26 & 46.83 \\
\hline 3 & $\begin{array}{l}\text { Increase knowledge on how } \\
\text { to optimize space for the } \\
\text { garden in the alley. }\end{array}$ & 35.95 & 87.98 & 52.03 \\
\hline 4 & $\begin{array}{l}\text { Increase knowledge about } \\
\text { the experience of how to } \\
\text { arrange a garden in the alley. }\end{array}$ & 27.87 & 78.99 & 51.12 \\
\hline 5 & $\begin{array}{l}\text { Increase knowledge about } \\
\text { gardening with mild steel. }\end{array}$ & 37.03 & 75.37 & 38.34 \\
\hline & Average & 35.90 & 83.27 & 47.37 \\
\hline
\end{tabular}

Based on Table 2 and Figure 3, it is known that the achievement of SIO before the service activities were held was $35.90 \%$. Then, after the service activities were held, it changed to $83.27 \%$. Therefore, it can be said that each SIO increased by an average of $47.37 \%$. This shows that the community's knowledge about making a Vertical garden using mild steel has increased significantly so that overall the initial objectives of this service activity have been achieved satisfactorily. This increase in citizen knowledge is expected to be transmitted to other residents in general so 
that they can synergize in improving community welfare (Fahrudin, 2012).

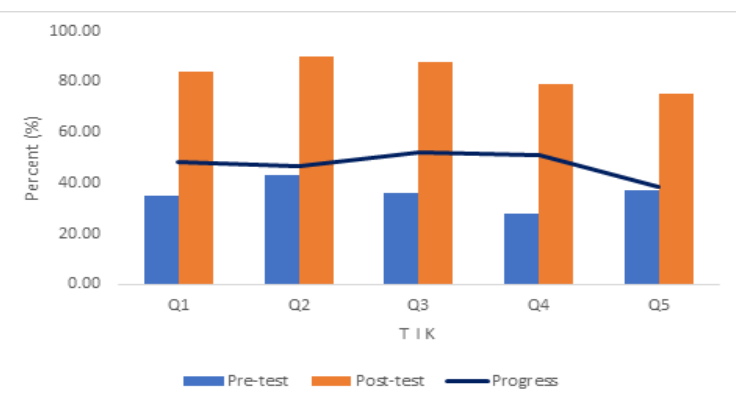

Gambar 3. Comparison of SIO achievements before and after service activities.

\section{CONCLUSION}

The implementation of community service through plant arrangement activities in the alley room using this mentoring method is useful for introducing and practising and is easily applied at the community level. Mentoring provided to residents is based on residents' preferences in creating greenery in front of beautiful alleys. Efforts to optimize space along the alley have succeeded in creating beauty and cleanliness in the alley environment.

In the current community service $(\mathrm{PkM})$ activity, assistance in the use of space is only carried out along the alley RT01/ RW03, Cibogor Village, Bogor City. The plants used in this mentoring activity are flower plants that grow around the residents' yards. The managerial implication from the results of this assistance is that residents can adopt other alley space utilization techniques with lightweight steel shelves. The development of productive gardens presents a variety of plants that are available around residents' homes such as varied from fruit plants, vegetables, rhizomes, toga (family medicinal plants), to ornamental plants. Alternatives to developing a productive garden with potted plants need to be considered with design modifications that facilitate maintenance and optimal light capture. Plants that have the benefit of being able to absorb carbon monoxide, carbon dioxide, cigarette smoke can be used as ornamental plants of the type of aglaonema, lidah mertua (Sansevieria) or the type of puring (Garden croton).

\section{REFERENCES}

Al-Ghifari, M. N., \& Firdausan, S. Z. (2020). Perilaku masyarakat pada ruang terbuka publik di kampung Kebangsren Surabaya. SineSIOa Jurnal Arsitektur, 16(2), 80-86.

Fahrudin, A. (2012). Pemberdayaan, partisipasi dan penguatan kapasitas masyarakat. Bandung: Humaniora.

Hasim, I. R. (2020). Unsur hijau pada ruang publik dan sisa halaman rumah kampung Cibunut RW 07 RT 05 kota Bandung. Jurnal Arsitektur TERRACOTTA, 3(1), 151-162

Irwan, S. N. R., \& Sarwadi, A. (2016). Pemanfaatan ruang terbatas sekitar rumah di permukiman perkotaan melalui pengembangan lanskap produktif. Paper presented at the Prosiding SEMNASTEK Fakultas Teknik, Universitas Muhammadiyah Jakarta.

Joga, N., \& Ismaun, I. (2011). RTH 30\% resolusi (kota) hijau. Jakarta: Gramedia Pustaka Utama.

Kusminingrum, N. (2008). Potensi tanaman dalam menyerap $\mathrm{CO} 2$ dan $\mathrm{CO}$ untuk mengurangi dampak pemanasan global. Jurnal Permukiman, 3(2), 96105. doi:10.31815/jp.2008.3.96-105

Noviana, L., \& Sukwika, T. (2020). Pemanfaatan sampah organik sebagai pupuk kompos ramah lingkungan di kelurahan Bhaktijaya Depok. Pengabdian Untukmu Negeri, 4(2), 237-241. doi:10.37859/ jpumri.v4i2.2155

Rosha, P. T., Fitriyana, M. N., \& Ulfa, S. F. (2016). Pemanfaatan sansevieria tanaman hias penyerap polutan sebagai upaya mengurangi pencemaran udara di kota Semarang. Jurnal Ilmiah Mahasiswa, $3(1), 1-6$.

Sukwika, T., \& Firmansyah, I. (2021). Alokasi pemanfaatan ruang berdasarkan daya dukung lahan di Sawangan, Depok. Majalah Ilmiah Globe, 23(1), 13-20. doi:10.24895/MIG.2021.23-1.1049 